\title{
Considering Local Integration for Refugees in Indonesia
}

\author{
Yessi Olivia \\ Department of International Relations, Universitas Riau, Pekanbaru, Indonesia \\ yessi.olivia@lecturer.unri.ac.id \\ Yusnarida Eka Nizmi \\ Department of International Relations, Universitas Riau, Pekanbaru, Indonesia \\ Ahmad Jamaan \\ Department of International Relations, Universitas Riau, Pekanbaru, Indonesia \\ Mohammad Saeri \\ Department of International Relations, Universitas Riau, Pekanbaru, Indonesia \\ Irwan Iskandar \\ Department of International Relations, Universitas Riau, Pekanbaru, Indonesia \\ Haniva Sekar Deanty \\ Department of International Relations, Universitas Riau, Pekanbaru, Indonesia \\ Submitted: 31 October 2020; Revised: 18 January 2021; Accepted: 21 January 2021
}

\begin{abstract}
Abstrak
Studi ini membahas tentang pengungsi yang tinggal bertahun-tahun di Indonesia sebagai negara transit. Mereka dihadapkan pada kenyataan bahwa kesempatan untuk ditempatkan di negara ketiga semakin kecil, sementara untuk kembali pulang ke negara masing-masing hanya akan membahayakan nasib mereka. Indonesia bukan negara yang meratifikasi Konvensi Pengungsi tahun 1951 yang menetapkan kewajiban bagi negara yang meratifikasinya untuk membantu asimilasi pengungsi. Namun begitu, Indonesia membuka pintunya untuk para pengungsi atas dasar solidaritas kemanusiaan dan karena fakta bahwa ada pengakuan hak seseorang untuk mencari suaka di negara lain dan prinsip non-refoulement di dalam kerangka hukum hak asasi manusia Indonesia. Situasinya menjadi lebih problematik ketika jumlah pengungsi yang masuk ke Indonesia terus bertambah tetapi proses pemukiman mereka di negara ketiga semakin tidak pasti, sementara kebijakan pengungsi yang komprehensif untuk membantu pengungsi tidak memadai. Dengan melihat penanganan pengungsi di Pekanbaru di bawah Peraturan Presiden Nomor 125 tahun 2016, studi ini menyarankan pemerintah Indonesia seharusnya mempertimbangkan program integrasi lokal sebagai salah satu solusi terhadap keberadaan protracted refugees ini.
\end{abstract}

Kata kunci: pengungsi, pengungsi menahun, integrasi pengungsi, negara transit.

\begin{abstract}
This study discusses refugees who have been stranded in Indonesia as a transit country. These protracted refugees have to deal with a reality that the chance of getting resettlement in a third country has become slim, and the option of returning to their origin country will only jeopardize their lives. Indonesia is not a state party to the 1951 Refugee Convention that lays a responsibility to assimilate refugees in the resettlement countries. Indonesia, however, has opened its door for refugees based on humanity's solidarity and the fact that Indonesia's legal framework on human rights acknowledges the right to seek asylum in other countries and abides by the non-refoulment principle. The situation has become problematic when the number of refugees coming to Indonesia has continued to increase, but Indonesia does not have a comprehensive refugee policy to support them. By looking at the case of refugee management in Pekanbaru under the President Regulation No. 125 of 2016, we suggest that Indonesia consider the local integration option a viable solution to the protracted refugee situations in Indonesia.
\end{abstract}

Keywords: refugees, protracted refugees, refugees integration, transit country.

\section{INTRODUCTION}

Indonesia has become a well-known transit country among refugees wanting to reach third countries like Australia (Hugo, Tan, \& Napitupulu, 2017). It is not an

easy ordeal for these refugees as they have to wait, sometimes for so many years, before a third country welcomes them. The number of refugees currently staying 
in Indonesia is relatively small than those seeking refuge in a country like Bangladesh or Malaysia (UNHCR Indonesia, 2020). However, Indonesia still needs a solution for these stranded refugees as problems might arise from their increasing numbers, and the government cannot just ignore them or deport them back to their country. In this paper, we argue that the government should consider the local integration option for protracted refugees, who, according to United Nations High Commissioner for Refugees (UNHCR), have lived for more than five years in the country they first took refuge. By granting them their right to work, for example, we can help reduce their dependencies on donors' assistance and empower them as human beings.

Presidential Regulation of the Republic of Indonesia No. 125 of 2016 (PP No. 125 Tahun 2016) concerning Handling of Refugees from Abroad; the latest regulation that the Indonesian government has produced to manage refugees, has so far provided helps in accepting asylum seekers, accommodating, and providing them with security. The refugees are bound to rules limiting their socio-economic mobilities and constant monitoring from the immigration service department and the local government. By studying the implementation of PP No. 125 Tahun 2016 and the experiences of refugees living in Pekanbaru, where some have long awaiting years, we suggest that the Indonesian government not neglect the refugee problems. The excuse that Indonesia is not a party to the 1951 Refugee Convention, and thus Indonesia is not bound to the responsibility to assimilate the refugees, only contradicts the mandate of the 1945 Constitution for Indonesia to "participate toward the establishment of a world order based on freedom, perpetual peace and social justice." It also repudiates the country's endorsement of the economic, social and cultural rights stipulated under the ratification of the International Covenant on Economic, Social and Cultural Rights and the International Convention on the Elimination of All Forms of Racial Discrimination.

During the field study, we interviewed 28 respondents from the government officials responsible for managing the refugees (Badan Kesatuan Bangsa dan Politik Kota Pekanbaru and Rumah Detensi Imigrasi Pekanbaru), a member of local people's representative council (DPRD Kota), community leaders and NGOs, UNHCR and IOM representatives and the refugees from Afghanistan, Iran, and Myanmar. Respondents were given open-ended questions. For the authorities, we looked at whether PP No. 125 Tahun 2016 has created differences in refugees' management. We also asked about challenges that the local government has faced since local governments have been granted more active roles with the issuance of PP No. 125 Tahun 2016. In our interviews with the local community, we asked about their perception of refugees and whether they communicate with them. As for the refugees, we asked about their living experience in Pekanbaru and how they cope with their situation.

The organization of this paper is as follows. The first part discusses the conceptual framework of refugee integration, how it originated, and how it is practiced. The next section discusses the dynamics of refugee protection in the context of Pekanbaru, the locus of the study. After laying out the foundation of our arguments in the first and second sections, we discuss why Indonesia should consider the local integration option. There have been a significant number of refugee studies in Indonesia (see Ali, Briskman, \& Fiske, 2016; Brown, 2017; Missbach, Adiputera, \& Prabandari, 2018; Triceseria, Zayda, \& Prabaningtyas, 2015), yet, on the issue of protracted refugees, it is still underdeveloped. We hope this paper will contribute to the burgeoning field.

\section{THEORETICAL FRAMEWORK}

Three concepts lay the groundwork for this research. First, a transit country, defining as "a country that refugees and migrants pass through along the way to their preferred country of asylum-it may be located anywhere between the country of origin and the country of destination" (Kilibarda, 2017, p. 215). What we refer to as a transit country is Indonesia, which according to UNHCR's report per July 2020, hosted 13,653 refugees from various countries from Afghanistan, Somalia, Iraq to Myanmar (UNHCR Indonesia, 2020). Its geographical feature close to countries with refugee resettlement programs in their refugee policy like Australia and New Zealand has made Indonesia one of the preferable transit 
countries for refugees, especially those coming from the Middle East (Missbach \& Sinanu, 2011). In Indonesia, these refugees reside in temporary accommodations scattered in several cities like Jakarta, Medan, Cisarua Bogor, Pekanbaru, and Makasar.

The second concept is integration. It is important to note that 'integration' is an elusive concept that lacks clarity or a consensus on defining it. Nevertheless, despite this conceptual problem, UNHCR and academics of refugee studies frequently employ the term when they talk about refugee settlement. Another thing to point out, the word 'integration' does not appear in the 1951 Refugee Convention; the legal text that becomes the basis for refugee protection applies the term 'assimilate' instead. Under Article 34, the Convention lays the responsibility of the host states to the refugees: "The Contracting States shall as far as possible facilitate the assimilation and naturalization of refugees" (UNHCR, 2010). Some scholars use 'integration' and 'assimilation' synonymously (Kibreab, 1989), while others treat them differently. (Kuhlman, 1991, p. 6), for example, it points out that 'assimilation' implies altering migrants' group identities almost to the point that they are "more or less indistinguishable from other members of their adopted society". What integration should be, according to Kuhlman, is the condition where "the migrants maintain their own identity, yet become part of the host society to the extent that host population and refugees can live together in an acceptable way" (p. 6).

Local integration, dubbed as one of "the durable solutions" for refugees (UNHCR, n.d.), is a multidimensional concept. Integration can be a legal process where refugees can enjoy a "wider range of rights" (Crisp, 2004, p. 1) stated under the 1951 Refugee Convention, such as freedom of movement, employment rights, or admission to the educational institution. This dimension can lead to the right to acquire permanent residence status, building a pathway for citizenship. The second feature of integration is related to economic empowerment. This integration element is by incorporating the refugees in economic activities; thus, they become independent and no longer dependant on aids from the government or humanitarian groups. The last aspect of integration is related to social bonding between the refugees and the locals. This dimension is instigated by "enabling refugees to live amongst or alongside the host population, without fear of systematic discrimination, intimidation or exploitation by the authorities or people of the asylum country" (Crisp, 2004, pp. 1-2). Crisp differentiates between 'local integration' with 'local settlement', other terminologies often mixed with the first concept. While local integration implies a long-lasting effect on the refugees, local settlement serves as a temporary solution that does not include the plan for the refugees. As Crisp points out, the local settlement was a popular approach used by African countries in the 1960s-1980s to relocate refugees' massive arrival to open land to live and sustain their lives by farming. As the host states recognized them as prima facie refugees, they did not process them and treat them by the 1951 Refugee Convention.

The third concept is associated with the phenomenon where some refugees must undergo long waiting periods in the country they first seek asylum, an experience often equated with living in limbo. To put it simply, living in limbo means the agony of unable to return to their home country due to the high risk, and thus they are stranded in a host country reluctant to take them as permanent residents and impose limits on their mobility, while at the same time facing uncertainties of whether or not a third country will approve their application for resettlement (Crisp, 2002). UNHCR calls the circumstance where refugees have been stranded living in a foreign country with no viable option to come to their home country or be relocated into a new country as 'protracted refugee situations'. In 2004, UNHCR defined protracted refugee situations as a condition "in which refugees find themselves in a long-lasting and intractable state of limbo." UNHCR set a specific perimeter of "populations of 25,000 persons or more who have been in exile for five years in developing countries (UNHCR, 2004). Such classification received criticisms for its impracticality. It tends to overlook the complexity of the refugee issues since there are fewer refugees in numbers but have been living in exile for longer than five years. Moreover, the quantitative limit that UNHCR formulated was also 
deemed problematic since collecting refugee statistics itself is correspondingly a challenging task (Milner, 2014). Therefore, in 2009 UNHCR dropped the threshold of 25,000 persons and clarified the definition of protracted refugee situations as the case where refugees confined "for five years or more after their initial displacement, without immediate prospects for implementation of durable solutions" (UNHCR, 2009). Living in limbo, whether in refugee campsites or urban refugee housings, is never easy. Some may have spent their lives in the asylum country because returning to their home country can put them in danger. Furthermore, even if they are no longer living in peril, protracted refugees find it hard to be independent and self-sufficient as they tend to be dependent upon the help of humanitarian groups to provide them with their basic needs (UNHCR, 2004).

According to UNHCR, in 2019, 16 million people lived in a protracted refugee situation. Among the ten largest protracted refugees are the Afghans, Syrians, South Sudanese, Rohingyas, and the Somalis. It is said that this figure is "a 12 percent increase" from 2018, and it "represents approximately 78 percent of all the refugees displaced worldwide" (UNHCR, 2020b). If we added that statistic with the number of Palestinian refugees administered under the UN Relief and Works Agency for Palestine Refugees in Near East (UNRWA), the sum of protracted refugees in the world could reach more than 20 million people (see United Nations, 2018).

Many factors arguably contribute to the prolongation of refugees' stay in asylum countries. Lui (2007) argues the nature of the international system, very state-centric, is one factor causing the abandonment of the people refuging in other countries. She provided an example where the minimum attention given to the refugee crisis in Asia was caused by the lack of regional and national mechanisms to deal with the problem. Others have looked more into the national level of analysis. UNHCR, for example, stated that the origin of protracted refugees situations was political deadlock from the home country and the asylum country (UNHCR, 2004, pp. 1-2):
Protracted refugee situations stem from political impasses. They are not inevitable but are rather the result of political action and inaction, both in the country of origin (the persecution or violence that led to flight) and in the country of asylum. They endure because of ongoing problems in the countries of origin and stagnate and become protracted as a result of responses to refugee inflows, typically involving restrictions on refugee movement and employment possibilities, and confinement to camps.

Long (2011) further explains the domestic politics factor driving people to move out from their countries. She argues that the displacement of people into another country where their stays can expand to more than decades is related to the state's absence in addressing the social problems in its country. Over time these social problems, such as poverty and insecurity, transform into violent conflicts, triggering the exodus of people seeking refuge in another country. Long points out the case of Afghan refugees living in Pakistan since the political crisis in Afghanistan, which then led to the Soviet invasion in 1979, as an example of a failed state contributing to protracted refugees. However, the state's failure in providing its people's needs is not the only problem. People also migrated from their country because of the suppression imposed by their authoritarian government. A notable example of this case is the flight of Rohingyas to Myanmar's neighboring countries in Southeast Asia originating from the systematic state discrimination and violence. In addition to problems deriving from the origin country, Long also argues that the inadequate migration policy to support refugees and the politicization of resettlement of the refugees contribute to the prolongation of refugees in the asylum countries. As pointed out by Long:

States should move to accept refugees for resettlement on the basis of protection needs alone while at the same time exploring opportunities to open up other regular migration routes to suitably qualified refugee candidates. UNHCR should seek to expand opportunities for recognized refugees to travel and seek work using Convention travel documents (p.21). 
As each argument has its strengths and weaknesses, what they have shown us is how complicated the refugee problem is and how each of the causes is interrelated. The failed state argument, for example, cannot be separated from how other states respond to the neighbor's crisis either through offering assistance bilaterally or the regional organization mechanism. Thus, if one has to find a solution for the refugee crisis, one must also address the multilevel challenges involving all the stakeholders, from states to the refugees themselves.

\section{RESEARCH METHOD}

This research used the qualitative case study approach as we intended to grasp particular events and to narrate "key aspects of the case" (Hancock \& Algozzine, 2006, p. 10). We applied the purposive sampling technique in selecting groups of respondents. Besides the refugees, the rest of the respondents approached were people who had direct interaction with them or involved in the implementation of refugees policy. Thus, we grouped four categories of respondents and interviewed 28 of them. The details of respondent groups as follows: 1) the government (six respondents from the City Council of Pekanbaru, two from the Immigration Office of Pekanbaru, and one from the local people's representative council--DPRD); 2) refugees (twelve respondents); 3) the local community from local NGOs to community leaders (five respondents); international organizations (IOM and UNHCR) (two respondents). We gave each respondent open-ended questions based on their role and experience as or with refugees. We planned to have an equal gender-based sample from refugees. However, due to the sensitive subject matter, most of our prospective female respondents from the refugees group declined to be interviewed. The delicate subject of refugees also caused some of our respondents opted to be anonymous. In addition to the primary data, we also relied on information from the government websites (e.g. the City Council of Pekanbaru and the Cabinet Secretariat of the Republic of Indonesia) to retrieve official documents or press releases; the local and national media that reported news on refugees in Indonesia; and other references such as academic publications or documents from organizations, like UNHCR, that involved in providing assisting the refugees. Phases for data analysis included data disassembling, interpreting, and concluding (see Yin, 2010). We sorted the data that highlighted the refugees problems in Indonesia and corroborated the findings with information we received from the interviews with the respondents to see whether the problem had been properly addressed.

\section{RESULT AND ANALYSIS REVITALIZING THE LOCAL INTEGRATION APPROACH}

Local integration, as previously mentioned, is one of the solutions that UNHCR suggested to break the dilemma of protracted refugees situations. The other two solutions are voluntary repatriation and resettlement. Repatriation is defined as a circumstance when refugees decided to return to their home country, and thus, their citizenship rights got restored. Resettlement is "the selection and transfer of refugees from a state in which they have sought protection to a third state that has agreed to admit them-as refugees-with permanent residence status" (UNHCR, 2020a). After the Cold War ended, refugee politics have changed how states perceived refugees and the UNHCR suggested solutions (Jacobsen, 2001). Local integration was once a widely chosen practice during the Cold War, especially among Western countries. States offered permanent asylum to refugees and encouraged them to integrate with society. While developing countries rarely granted permanent residency or took the local integration option, they let refugees come into their territory to resettle next to the locals. This hospitality mode has changed after the Cold War ended, especially since people started to securitize the refugee issue. Fueled by xenophobia, refugees are seen as liabilities, associated with criminal activities, and regarded as a security threat (see Hovil, 2014; Jacobsen, 2001). Consequently, the government has a growing tendency to adopt a protectionist approach and ignore the "free integration" idea when dealing with the refugee crisis (Hovil, 2014, p. 491). Developing countries are said to follow the unwillingness of the developed countries to 
adopt the local integration approach. Only a small number of countries employed the local integration option (see Fielden, 2008), while some others treated refugees as prima facie refugees that eliminated their rights written in the 1951 Convention. Self-settlement, a popular approach for developing countries during the Cold War, has also become less practiced.

We support Jacobsen's argument on the need to revive the local integration option because informal integration (e.g., social acceptance by the locals) has already taken place even when the government does not support the formal integration (i.e., obtaining citizenship) of refugees. According to Jacobsen, such a process is likely to happen if refugees are not kept in camps, live free from threat, access public facilities, and socialize with the locals (Jacobsen, 2001). The argument for local integration certainly raises a question on how to support or execute the plan? Jacobsen underlines two prerequisites necessary in revitalizing local integration. First, refugees, the local community, and the host government must come to terms with local integration feasibility. It means that they must clarify these concerns: under what circumstance that local integration practical? and what are "the needs and concerns" (p.4) of the stakeholders? Second, Jacobsen mentions that repatriation must be included in the local integration program. Freedom of movement from host countries to origin countries is what characterizes protracted situations, and "incorporating return migration into a policy of local integration will make it more acceptable to both refugees and host countries" (p.5). As Jacobsen points out, there is a misconception held by many that refugees who went through a local integration program will not return to their home countries. However, studies have shown a contrary result, since refugees tend to choose to repatriate as normalcy and stability return to their countries (see Bahar, Özgüzel, Hauptmann, \& Rapoport, 2019; Fresia, 2014; Weima, 2017).

Jacobsen lays out six key groups (stakeholders) whose interests will determine the success of the local integration: UNHCR, NGOs, the host government, the local population, donors, and the refugees. As she stated: "Local integration depends on the goodwill of key groups in the host country. In the absence of this goodwill, refugees will find it more difficult to settle amongst the community and become integrated" (p.10). Thus, what should be done first, is to study "the full range of interests" (p. 10) of each stakeholder to review the possible complications that might hinder the integration process whether the concerns of security, burden sharing on economic resources, or cultural differences. Jacobsen underlines the importance of facilitating the refugees to become self-sufficient through imposing freedom of movement and contributing to the locals' economy and growth. It is achievable if the government clarifies the legal status of the refugees to reside and move freely and that the government and UNHCR produce assistance programs that can benefit the refugees as well as the locals.

While Jacobsen emphasizes the role of institutions, the government and organizations like UNHCR, another significant factor that should not be overlooked is the role of refugees themselves. The concern of what kind of needs they want and how they will negotiate that needs with local actors is vital if we regard socio-economic integration as "the best solution" to have their basic rights (Polzer, 2009, p. 97). In regards to local integration policies, best practice conducted by several countries like Morocco, Belarus, and Brazil, show a wide range of solutions offered to the refugees, from housing, vocational and language training, access to educational institutions, to employment support (Moreira \& Baeninger, 2010; UNHCR, 2015). Some cases also feature civil society organizations and religious institutions, such as churches, in empowering refugees. These programs are not without problems. As the case in Brazil shows, challenges to local integration, such as the lack of employment and discrimination, remains (Moreira \& Baeninger, 2010). 


\section{LIVING IN LEGAL LIMBO IN INDONESIA}

According to UNHCR Indonesia (2020), as of July 2020 , there were 13,653 foreigners registered as refugees and asylum seekers in Indonesia. Most of them come from Afghanistan (56\%), Somalia (10\%), Iraq (6\%), and around $643(4.7 \%)$ of refugees are without states-the statistic of the stateless refugees in Indonesia might be higher than UNHCR's estimation. If we compare Indonesia to other Asian countries that also host refugees in their territories, Indonesia looks after a considerably lower number of refugees. Indonesia is far behind Bangladesh that hosts more than 860,000 refugees, and even with its neighbor Malaysia that manages 177,000 refugees. These refugees see Indonesia as a transit country where UNHCR then refer them to other countries like Australia or New Zealand. They came to Indonesia using different modes of transportation-by boats and planes; methods-illegally or legally through tourist visa; and causes-running away from prosecution or victims of human smuggling (Susetyo, 2020).

Indonesia is not a signatory party to the 1951 Refugee Convention, and, thus, it has relieved the country from the responsibility to grant refugees their rights as stated in the treaty. Despite this circumstance, Indonesia has continued to accept the arrival of refugees based on humanity and the fact that repulsing them contradicts the non-refoulment principle stipulated under Indonesia's laws on human rights. The legal loophole implies that refugees who seek refuge in Indonesia only have limited choices. They cannot travel freely or look for employment to support their lives (Missbach, 2017). For asylum seekers who come to UNHCR to obtain refugee status, their lives depend on UNHCR and IOM's assistance-these international organizations themselves rely on donors' contributions. In addition to the UNHCR and IOM administered refugees, there are approximately 5000 self-funded refugees (pengungsi mandiri), which, as the name implies, rely on themselves to live in Indonesia (Pudjiastuti, 2020). Unfortunately for these refugees, the future is looking grim. As third countries such as Australia or the United States imposed stricter refugee policy, the chance for getting resettlement in third countries has become slim. In 2019, there were only 720 refugees from Indonesia relocated to third countries through resettlement or sponsor programs (UNHCR Indonesia, 2020). This small figure has only projected what living in legal limbo is, especially for those who have spent more than five years in Indonesia with uncertainty ahead of them (Liputan 6, 2019). If this trend continues to happen, the number of protracted refugees in Indonesia will grow, and Indonesia will have to deal with more complicated problems.

\section{A VIEW FROM PEKANBARU}

According to UNHCR Indonesia (2020), as of July 2020 , there were 13,653 foreigners registered as refugees and asylum seekers in Indonesia. Most of them come from Afghanistan (56\%), Somalia (10\%), Iraq (6\%), and around $643(4.7 \%)$ of refugees are without states-the statistic of the stateless refugees in Indonesia might be higher than UNHCR's estimation. If we compare Indonesia to other Asian countries that also host refugees in their territories, Indonesia looks after a considerably lower number of refugees. Indonesia is far behind Bangladesh that hosts more than 860,000 refugees, and even with its neighbor Malaysia that manages 177,000 refugees. These refugees see Indonesia as a transit country where UNHCR then refer them to other countries like Australia or New Zealand. They came to Indonesia using different modes of transportation-by boats and planes; methods-illegally or legally through tourist visa; and causes-running away from prosecution or victims of human smuggling (Susetyo, 2020).

Pekanbaru is one of five cities in Indonesia alongside Jakarta, Medan, Makasar, and Tanjung Pinang, where UNHCR representatives operate. Besides UNHCR, Pekanbaru is also where IOM places one of its representative offices to administer the refugees. Based on the data from Rumah Detensi Imigrasi Pekanbaru (2020), there were currently 984 refugees live in Pekanbaru per July 2020; most of them are from Afghanistan (827), followed by Myanmar (34) and Sudan (30). Other countries of origin are Pakistan, Somalia, Palestine, Iraq and Iran. Unlike other big cities, such as Jakarta, Medan, or Makasar, Pekanbaru hosts a relatively small number of refugees. Most of them are managed by 
UNHCR and IOM in Pekanbaru-only one family chose to be self-reliant. Again, this condition is different from other Indonesian cities, where the number of independent and unregistered refugees is abundant.

Most of the refugees we interviewed have spent 4-8 years living in Pekanbaru, which means that they have met the category of protracted refugee situations defined by UNHCR. Some were relocated to Pekanbaru from other cities in Indonesia (e.g., Bogor), while others chose Pekanbaru as their first entrance to Indonesia. They have different employment backgrounds, from professional to low-income jobs. Some came to Indonesia from their home country using Indonesia's lax visa policy, and others went through such hardship, trafficked by smugglers from country to country. A respondent from Afghanistan (Rahim, 2020) took three months to get from Afghanistan to Indonesia by taking land and sea routes, while a respondent from Myanmar described his journey as a painful experience as the boat he took to Indonesia stranded at sea (Malik, 2020).

They live in a community shelter that IOM provided-there are eight community houses spread across Pekanbaru. Since they live close to the local community, the interaction between them and the neighborhood people is anticipated. Refugees told us that they have adjusted and participated in local norms and practices, such as gotong royong, religious sermons and celebrations, or vaccination at the local health post (Posyandu). While the general attitude of the locals is welcoming toward the refugees, some of the refugees admitted that they had bad experiences with the locals. One respondent recalled that he had to clarify the misinformation that led to the resentment of the local people to the refugees, which they thought only took advantage of the Indonesian government. "Indonesia welcomes us, support us... they are just driven by jealousy. I do not know where they get that information" (Madin, 2020). Another way that refugees have taken to break the social barriers with the locals is learning Bahasa Indonesia. Some of the protracted refugees we met have mastered Bahasa Indonesia, either through self-study or direct communication with Indonesians who befriended them. One respondent told us that he regretted not paying enough attention to learning Bahasa Indonesia when coming to Indonesia because he thought his stay would be short, yet, he has been stuck living in Indonesia for eight years (Rahim, 2020).

Refugees were satisfied that they could normally live side by side with the locals, not living in a detention house. However, they complained about the limitation imposed on them by the government, from scheduled hours of when they can go in and out of the community houses, prohibited from married while living in Indonesia, barred from traveling outside the city limit and admission to higher educational institutions. They are even not allowed to apply for a job even though the job is informal. Malik, who got caught by the Immigration Office for teaching Qur'an recitation to children in his neighborhood, had to spend some time in the detention house, an experience that traumatized him. On the issue of marriage, Rahim, as he pointed out to his fellow refugees of age 20-30, said: "I am the focal point [of the refugees] and know everything going on. Most refugees are singles, but they are not allowed to get married here. It is depressing." Maheen (2020) wanted to pursue a higher degree: "We do not have permission to work and study. I hope the Indonesian government at least permits us to study if they do not want us to get a job. I want to go to university to pursue a Master's degree, but unfortunately, we do not have that opportunity."

What we have seen from our interviews with refugees in Pekanbaru is relatively similar to elsewhere in Indonesia. They have to live a life where the future is uncertain, and they do not have other places to go but to wait in a country that limits their rights. Out of frustration, on August 9, 2019, a group of refugees held a protest in front of UNHCR and IOM's representative offices in Pekanbaru, demanding the organizations to find a solution to their problems (Liputan 6, 2019). In responding to the event, the UNHCR's representative that we interviewed pointed out that while it is the responsibility of UNHCR to assist refugees in applying for resettlement, the final word is not from them but the governments of the third countries (Syukri, 2020). 


\section{PP. NO. 125 TAHUN 2016, A GOOD SIGN BUT NOT ENOUGH}

On July 25, 2017, the Indonesian government adopted PP No. 125 Tahun 2016, a regulation that has become the legal basis for managing refugees in Indonesia. Seventeen years since the passing of Law No. 37 (Undang Undang Nomor 37), stating the need for a follow-up policy that details the handling of refugees in 1999, this law is certainly a long time coming. Previously, in the absence of an authorization policy to assist refugees, people arriving in the country to seek asylum were treated as illegal immigrants and held in detention houses by the Immigration Office until UNHCR granted their status as refugees (Utami, 2019).

On the one hand, PP No. 125 Tahun 2016 is a positive sign regarding refugee protection in Indonesia. Despite being a non-signatory party to the 1951 Refugee Convention, Indonesia has taken the responsibility to assist refugees under a formal legal framework. It replaces the ad-hoc measures that were once overseen by the Immigration Office. Moreover, it reinforces the responsible agencies, which include "the Ministry of Law and Human Rights, Ministry of Foreign Affairs, Coordinating Ministry of Politics, Law and Security, Directorate General of Immigration, as well as UNHCR and a handful of NGOs" (Prabandari \& Adiputera, 2019, p. 141). The handling of refugees under PP No. 125 Tahun 2016 also indicates an active role of local governments in handling refugees residing in their area. At the local government, one of the follow-ups of PP No. 125 Tahun 2016 is the formation of a special task force consisting of the representatives from the local Immigration Office, the National and Political Unity Agency (Badan Kesatuan Bangsa dan Politik-Kesbangpol), and UNHCR. When we conducted this research, Pekanbaru's task force for refugee assistance was at its earlier stage of operating. In our discussion with respondents from Kesbangpol and UNHCR, this task force aims to smooth coordination between members of the unit and serves as a communication channel to find a solution to refugee-related problems.
On the other hand, PP No. 125 Tahun 2016 has barely moved the needle to improve the refugee situation in Indonesia. It only goes so far as to validate "existing practices" (Missbach et al., 2018, p. 20). Even before adopting the presidential regulation, the Immigration Office, as the government agency responsible for managing refugees, had to coordinate with other local government agencies such as Kesbangpol, the police, social services, governor and mayor offices, as well as UNHCR and IOM. Moreover, while the regional autonomy policy allows local governments to arrange their public spending, it does not mean that assistance to refugees is available or sustainable as it depends on the political will of the local governments. On the issue of providing the educational right, for example, the city of Pekanbaru has initiated to offer children refugees access to primary education. However, the city council admitted that they ran a limited budget; thus, these children did not get the same treatment as the local residents (Pemko Pekanbaru, 2019). Children refugees were only treated as fillers to meet a quota of students as public schools prioritize local students, which means not all of them could have the chance to go to school. The city council also insisted that the children refugees would only receive a statement letter, not an official transcript or a certificate from the school boards, regardless of its essential role for their future education. Our respondent from the Local People's Representative Council (Dewan Perwakilan Rakyat Daerah-DPRD) also brought up financial issues regarding the refugee situation in Pekanbaru. Since we conducted this research when the COVID-19 pandemic has significantly impacted the global economy, our respondent mentioned the limit that the city has to assist refugees as many lower-income families require government help.

In addition to the deficiencies of PP No. 125 Tahun 2016 that resulted in the budget availability and the commitment problems (see Missbach et al., 2018), what makes the rule problematic is it does not tell us the position of the Indonesian government concerning the protracted refugee situation in Indonesia. What is the solution for the people whose chances of resettling in a third country have become smaller every day and the 
option of returning to their home country will only jeopardize their lives? Although we do not doubt the significance of the discussion of whether or not Indonesia should ratify the 1951 Refugee Convention, we believe it will only move us away from the main problem of refugees stranded in the country.

PP No. 125 Tahun 2016, albeit its slow development and weaknesses, has demonstrated that Indonesia is willing to respond to the changing environment. Thus, why not start making changes that lead to the improvement of refugees in Indonesia? The local integration framework developed by Jacobsen (2001) is one of the viable solutions to protracted refugee situations. It is important to note here, the local integration does not automatically imply the naturalization of the refugees. It can take various shapes and forms as long as all stakeholders, from the national and local governments, UNHCR, local communities to refugees, agree on the type of integration plan they want to pursue. One of the integration steps highlighted by Jacobsen is the need to ease the economic restriction to the refugees:

Enabling refugees to become self-sufficient and part of the local community does not necessarily mean that governments should allocate land to refugees or give them special privileges... Freedom of movement (itself an enshrined right of refugees) means that refugees have the opportunity to become economically active and participate in the local economy, contributing to its growth rather than wasting their economic potential in camps (p. 23).

In the Indonesian context, several studies have suggested that economic empowerment for refugees is workable because the number of refugees in Indonesia is smaller than the total workforce in the country. Adiputera and Prabandari (2018) argue that employments will be beneficial not only to the refugees but also to the host country as refugees might take an active role in creating job opportunities. While Locastro, Alfath \& Hu (2019) suggest the government and supporting organizations to encourage refugees to take internships, entrepreneurship, vocational programs, access to education from primary to tertiary levels, and language training. These are similar programs practiced to empower refugees in other countries (see Jabbar \& Zaza, 2016; Smith et al., 2019). We want to emphasize the vital role of social integration in supporting economic empowerment programs. The social aspect of local integration is quite a challenge mainly because not all stakeholders have the complexity of refugee issues. Thus, it requires coordinated work from the government, NGOs, and international organizations to address the social distrust, racial and religious discrimination, and other social problems from local integration.

\section{CONCLUSION}

The adoption of PP No. 125 Tahun 2016, regarded as an essential milestone to Indonesia's approach to handling refugees in Indonesia, has left a question on how to deal with protracted refugees? This paper has suggested the government to consider the option of local integration. Local integration does not mean the obligation to grant citizenship for the refugee but to allow them basic rights, such as employment access. This study provides an insight into how PP No. 125 Tahun 2016 has missed the main problem with refugees. Many refugees have been stuck in Indonesia for many years with little possibility of returning to their home country and getting resettlement in a third country. Restricting their movements have only put more burden on them, especially for those coming with their families. Providing them leeway to be self-reliant and let them integrate with the local community are viable solutions. As suggested in the discussion, the local integration program does not solely rest on the government's shoulder. All stakeholders, from the government, local community, supporting organizations, and the refugees, should be involved in designing the local integration program that will benefit all. 


\section{REFERENCE}

Adiputera, Y., \& Prabandari, A. (2018). Addressing challenges and identifying opportunities for refugee access to employment in Indonesia. Institute of International Studies Policy Brief.

Ali, M., Briskman, L., \& Fiske, L. (2016). Asylum seekers and refugees in Indonesia: problems and potentials.

Cosmopolitan Civil Societies Journal 8(2), 22-42.

Bahar, D., Özgüzel, C., Hauptmann, A., \& Rapoport, H. (2019). Migration and post-conflict reconstruction: The effect of returning refugees on export performance in the former Yugoslavia. IZA Discussion Paper, (12412).

Brown, T. (2017). After the boats stopped: Refugees managing a life of protracted limbo in Indonesia. Antropologi Indonesia, 34-50.

Crisp, J. (2002). The problem of protracted refugee situations in Africa. Working Paper, (68). Center for Comparative Immigration Studies

Crisp, J. (2004). The local integration and local settlement of refugees: A conceptual and historical analysis. Working Paper (102).

Fielden, A. (2008). Local integration: an under-reported solution to protracted refugee situations UNHCR Research Paper, (158).

Fresia, M. (2014). Performing repatriation? The role of refugee aid in shaping new beginnings in Mauritania. Development and Change, 45(3), 434-457.

Hancock, D. R. \& Algozzine, B. (2006). Doing case study research. New York: College Press.

Hugo, G., Tan, G., \& Napitupulu, C. J. (2017). Indonesia as a transit country in irregular migration to Australia. In M. McAuliffe \& K. Koser (Eds.), A long way to go: Irregular migration patterns, processes, drivers and decision-making. Canberra: ANU Press.

Hovil, L. (2014). Local integration. In E. Fiddian-Qasmiyeh, G. Loescher, K. Long, \& N. Sigona (Eds.), The Oxford handbook of refugee and forced migration studies (pp. 488-498). Oxford: Oxford University Press.

Jabbar, S. A., \& Zaza, H. I. (2016). Evaluating a vocational training programme for women refugees at the Zaatari camp in Jordan: women empowerment: a journey not an output. International Journal of Adolescence and Youth 21(3), 304-319.

Jacobsen, K. (2001). The forgotten solution: Local integration for refugees in developing countries. UNHCR Working Paper, (45).

Kibreab, G. (1989). Local settlements in Africa: A misconceived option?. Journal of Refugees Studies, 2(4), 468-490.

Kilibarda, P. (2017). Obligations of transit countries under refugee law: A Western Balkans case study. International Review of the Red Cross, 99(1), 211-239.

Kuhlman, T. (1991). The economic integration of refugees in developing countries: A research model. Journal of Refugee Studies, 4(10), 1-20.

Liputan 6. (2019, 9 August). Harap-harap cemas ribuan pencari suaka di Pekanbaru merajut masa depan. Retrieved January 17, 2021, from https://www.liputan6.com/region al/read/4033206/harap-harap-cemas-ribuan-pencari-sua ka-di-pekanbaru-merajut-masa-depan
Locastro, M., Alfath, D., \& Hu, G. (2019). Menjelaskan potensi ekonomi komunitas pengungsi Indonesia: Survei mengenai karakteristik ketenagakerjaan dan penghidupan. Sandya Institute Research Paper.

Long, K. (2011). Permanent crises? Unlocking the protracted displacement of refugees and internally displaced persons. Refugee Studies Centre, University of Oxford.

Lui, R. N. (2007). Such a long journey: Protracted refugee situations in Asia. Global Change, Peace \& Security, 19(3), 185-203.

Madin. (2020, 18 June) Taking refuge in Indonesia/Interviewer: $H$. S. Deanty.

Maheen. (2020, 18 June) Taking refuge in Indonesia/Interviewer: H. S. Deanty.

Malik. (2020, 15 June) Taking refuge in Indonesia/Interviewer: $M$. Saeri \& A. Jamaan.

Milner, J. (2014). Protracted refugee situations. In E. Fiddian-Qas miyeh, G. Loescher, K. Long, \& N. Sigona (Eds.), The Oxford handbook of refugee and forced migration studies (pp. 151-162). Oxford: Oxford University Press.

Missbach, A. (2017). Accommodating asylum seekers and refugees in Indonesia: From immigration detention to containment in "alternatives to detention". Refuge: Canada's Journal on Refugees/Refuge: revue canadienne sur les réfugiés, 33(2), 32-44.

Missbach, A., Adiputera, Y., \& Prabandari, A. (2018). Is Makassar a 'sanctuary city'? Migration governance in Indonesia after the 'local turn'. Austrian Journal of South-East Asian Studies, $11(2), 199-216$.

Missbach, A., Adiputera, Y., Prabandari, A., Cintika, G., Swastika, F. Y., \& Darningtyas, R. (2018). Stalemate: Refugees in Indonesia_Presidential Regulation No 125 of 2016. CILIS Policy Paper, (14).

Missbach, A., \& Sinanu, F. (2011). The scum of the earth? Foreign people smugglers and their local counterparts in Indonesia. Journal of Current Southeast Asian Affairs, 30(4), 57-87.

Moreira, J. B., \& Baeninger, R. (2010). Local integration of refugees in Brazil. Forced Migration Reviews, (35).

Pemko Pekanbaru. (2019). Pemko Pekanbaru beri akses pendidikan bagi anak imigran. Retrieved January 17, 2021, from https://www.pekanbaru.go.id/p/news/pemko-pekanba ru-beri-akses-pendidikan-bagi-anak-imigran-nbsp-

Polzer, T. (2009). Negotiating rights: The politics of local integration. Refuge, 26(2), 92-106.

Prabandari, A., \& Adiputera, Y. (2019). Alternative paths to refugee and asylum seeker protection in Malaysia and Indonesia. Asian and Pacific Migration Journal, 28(2), 132-154.

Pudjiastuti, T. N. (2020). Kerentanan pengungsi pada masa pandemi COVID-19 di Indonesia. Retrieved January 17, 2021, from http://www.politik.lipi.go.id/kolom/ko lom-1/politik-internasional/1384-kerentanan-pengungsi-pa da-masa-pandemi-covid-19-di-indonesia

Rahim. (2020, 18 June) Taking refuge in Indonesia/Interviewer: $H$. S. Deanty.

Smith, L., Howard, D. A., Giordano, M., Yossinger, N. S., Kinne, L., \& Martin, S. F. (2019). Management in protracted refugee camps: Findings from a study in the horn of Africa. Journal of Refugee Studies. Retrieved January 17, 2021, from 
164 JURNAL HUBUNGAN INTERNASIONAL VOL. 9, N0. 2 (2020): October 2020-March 2021

https://doi-org.ezproxy.flinders.edu.au/10.1093/jrs/fez010

Susetyo, H. (2020). Lost in transit: Refugees stranded in a legal vacuum in Indonesia. Retrieved January 17, 2021, from https://www.kaldorcentre.unsw.edu.au/publica tion/lost-transit-refugees-stranded-legal-vacuum-indonesia Syukri, M. R. (2020, 8 June) Managing refugees in Pekanbaru/Interviewer: A. Jamaan, M. Saeri, Y. Olivia, \& Y. E. Nizmi.

Triceseria, A. A. I. D., Zayda, N. A., \& Prabaningtyas, R. F. (2015). A new approach to refugee's welfare through the role of community: Case study of refugee's community centre in Sewon. Global South Review, 2(1), 1-12.

UNHCR. (2004). Protracted refugee situation' Executive Committee of the High Commissioner's Programme Standing Committee, 30th Meeting. (UN Doc. EC/54/SC/CRP. 14).

UNHCR. (2009). Conclusion on protracted refugee situations no. 109 (LXI). Retrieved January 17, 2021, from https://ww w.unhcr.org/excom/exconc/4b332bca9/conclusion-protract ed-refugee-situations.html

UNHCR. (2010). Convention and protocol relating to the status of refugees. Retrieved January 17, 2021, from https://www.un hcr.org/3b66c2aa10

UNHCR. (2015). The 10-point plan in action. Retrieved January 17, 2021, from https://www.unhcr.org/publications/manu als/5846d10e7/10-point-plan-action-2016-update-chap ter-7-solutions-refugees.html

UNHCR. (2020a). Information on UNHCR resettlement. Retrieved January 17, 2021, from https://www.unhcr.org/en-us/infor mation-on-unhcr-resettlement.html

UNHCR. (2020b). Protracted refugee situations explained. Retrieved January 17, 2021, from https://www.unrefu gees.org/news/protracted-refugee-situations-ex plained/\#How\%20many\%20refugees\%20are\%20liv ing\%20in\%20protracted\%20situations?

UNHCR. (n.d.). Local integration. Retrieved January 17, 2021, from https://www.unhcr.org/local-integration-49c3646c101.html

UNHCR Indonesia. (2020). Sekilas data. Retrieved January 17 , 2021, from https://www.unhcr.org/id/figures-at-a-glance

United Nations. (2018). The question of Palestine. Retrieved January 17, 2021, from https://www.un.org/unispal/docu ment/unrwa-release-annual-report-on-health-of-pales tine-refugees-unrwa-press-release/

Utami, P. N. (2019). Implementasi Peraturan Presiden Nomor 125 Tahun 2016 tentang Penanganan Pengungsi dari Luar Negeri di Provinsi Kepulauan Riau. Jurnal Legislasi Indonesia, 16(3), 299-312.

Weima, Y. (2017). Refugee repatriation and ongoing transnationalisms. Transnational Social Review, 7(1), 113-117.

Yin, R. K. (2010). Qualitative research from start to finish. New York: Guilford Press. 